\title{
IDENTIFIKASI FIBRILASI ATRIUM PADA ISYARAT ELEKTROKARDIOGRAM (EKG) MENGGUNAKAN SUPPORT VECTOR MACHINE (SVM)
}

\author{
Mohammad Rofi'i \\ Program Studi Teknik Elektro Medik \\ Akademi Teknik Elektro Medik Semarang \\ Email: mohmdrofii@gmail.com
}

\begin{abstract}
ABSTRAK
Jantung merupakan salah satu organ penting yang terdapat pada tubuh manusia. Fungsi vital yang diperankan oleh organ jantung berpengaruh besar terhadap kondisi seseorang yang dapat dilihat dari isyarat fisiologi yang dihasilkan oleh aktivitas kelistrikan jantung yang dapat diukur dan direkam berupa electrocardiogram (EKG). Tujuan dari penelitian ini adalah untuk mengidentifikasi kelainan jantung atau aritmia berupa atrial fibrillation (AF) pada isyarat EKG. Data penelitian yang digunakan berasal dari Rumah Sakit Umum Daerah Tugurejo Semarang yang terdiri dari data pasien dengan kasus atrial fibrillation (AF) dan data ECG normal atau normal sinus rhythm (NSR). Data yang diambil dalam bentuk data cetak, selanjutnya di lakukan scanning untuk mendapatkan data citra digital agar dapat diproses dengan komputer. Pada penelitian ini terdapat beberapa tahapan, diantaranya adalah pra-pengolahan, ekstraksi ciri, dan klasifikasi. Proses ekstraksi ciri berdasarkan ciri statistik (mean, standard deviation, kurtosis, variance, skewness) isyarat periodogram dari EKG, selanjutnya diklasifikasi menggunakan algoritma Support Vector Machine (SVM) dan Naive bayes Classifier (NBC) sebagai algoritma pembanding. Hasil yang didapatkan pada penelitian ini, SVM memiliki kinerja yang lebih baik dengan nilai akurasi sebesar sebesar $84,0 \%$, sensitivitas $80,5 \%$, dan spesifisitas $92,8 \%$.
\end{abstract}

Kata kunci: fibrilasi atrium, elektrokardiogram, SVM, NBC, periodogram.

\begin{abstract}
The heart is one of the important organs in the human body. The vital function of the heart organ affects the person's condition which can be seen from the physiological signal resulting from the electrical activity of the heart and can be measured, recorded on an electrocardiogram (ECG). The aim of this study was to identify cardiac or arrhythmic abnormalities of atrial fibrillation (AF) on electrocardiogram signal. Data on this research from RSUD Tugurejo Semarang consisting of patient data with cases of atrial fibrillation $(A F)$ and normal sinus rhythm (NSR) and analog data is converted to digital (digitized) by scanning. In this study there are several stages, is pre-processing, feature extraction, and classification. Feature extraction based on statistical (mean, standard deviation, kurtosis, variance, skewness) of periodogram signal from ECG. Furthermore, the classification stage uses the Support Vector Machine (SVM) and Naive bayes Classifier (NBC) algorithms as a comparator algorithm. The results of this study, SVM has a better performance with an accuracy of $84.0 \%$, sensitivity $80.5 \%$, and specificity $92.8 \%$.
\end{abstract}

Keywords: atrial fibrillation, electrocardiogram, SVM, NBC, periodogram.

\section{PENDAHULUAN}

Penyakit kardiovaskuler adalah penyakit yang disebabkan gangguan fungsi jantung dan pembuluh darah. Berdasarkan data dari badan kesehatan dunia (WHO) menempatkan abnormalitas jantung sebagai urutan teratas daftar penyebab utama kematian di seluruh dunia [1]. Jantung merupakan suatu organ otot berongga yang terletak di pusat dada. Fungsi utama jantung adalah menyediakan oksigen ke seluruh tubuh dan membersihkan tubuh dari hasil metabolism (karbon dioksida). Jantung melaksanakan fungsi tersebut dengan mengumpulkan darah yang kekurangan oksigen dari seluruh tubuh dan memompanya kedalam paru-paru, dimana darah akan mengambil oksigen dan membuang karbon dioksida, jantung kemudian mengumpulkan darah yang kaya oksigen dari paru-paru dan memompanya ke jaringan di seluruh tubuh [2][3]. Fungsi vital yang diperankan oleh organ yang satu ini berpengaruh besar terhadap kondisi seseorang yang dapat dilihat dari isyarat yang dihasilkan oleh aktivitas kelistrikan jantung. Electrocardiogram merupakan salah satu rekaman isyarat fisiologi utama yang dihasilkan dari aktivitas kelistrikan jantung baik ketika fase repolarisation maupun depolarization [4]. Electrocardiogram (ECG) 
pertama kali diperkenalkan oleh Augustus Desire Waller pada tahun 1887 [4]. Sejak saat itu ECG menjadi salah satu isyarat yang penting dan paling sering digunakan untuk melakukan analisis terhadap aktivitas jantung [4][5][6] dan telah menjadi golden standard untuk diagnosis aritmia jantung [7]. Penelitian terhadap isyarat yang dihasilkan oleh jantung dengan menggunakan bantuan teknologi komputer sudah banyak dilakukan [8]. Sehingga hal tersebut dapat dimanfaatkan oleh dokter ataupun tenaga medis dalam membaca dan menganalisis isyarat jantung yang dapat menampilkan abnormalitas aktivitas jantung. Hal itu merupakan salah satu media bantu dibidang kedokteran yang diharapkan oleh semua orang dalam rangkan meningkatkan pelayanan kesehatan di seluruh dunia.

Kelainan bentuk isyarat ECG biasanya disebut aritmia. Aritmia merupakan istilah umum untuk setiap irama jantung yang berbeda dari irama sinus normal jantung atau normal sinus rhythm (NSR) [9][10]. Aritmia yang paling umum dan yang sering dijumpai adalah atrial fibrillation (AF) [11]. Fibrilasi atrium atau AF didefinisikan sebagai irama jantung yang abnormal. Aktivitas listrik jantung yang cepat dan tidak beraturan mengakibatkan atrium bekerja terus menerus menghantarkan impuls ke nodus AV sehingga respon ventrikel menjadi ireguler. Fibrilasi atrium dapat bersifat akut maupun kronik dan umumnya terjadi pada usia di atas 50 tahun [12]. Atrial fibrillation $(A F)$ memang telah menjadi jenis aritmia yang paling umum dan paling banyak terjadi dengan prevalensi meningkat setiap tahunya.

Atrial fibrillation $(A F)$ merupakan salah satu karakteristik takiaritmia. Hal ini ditandai dengan tidak terkoordinasinya aktivitas atrial sehingga terjadi kemunduran pada fungsi mekanik atrial. Pada gambaran electrocardiogram, fibrilasi atrium digambarkan sebagai tidak adanya gelombang $\mathrm{P}$ normal yang telah diganti dengan gelombang fibrillatory (Gambar 1) yang bervariasi dalam ukuran, bentuk, dan timing [13], juga terjadinya respon ireguler dari ventrikel ketika konduksi atrioventricular (AV) dibatasi [14].

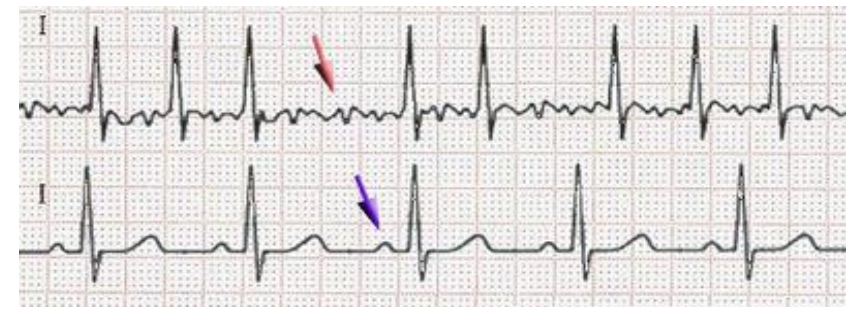

\section{Gambar 1. Gelombang P Yang Diganti Dengan Gelombang Fibrillatory}

AF diperkirakan berpengaruh terhadap 0,5\% sampai 1\% dari penduduk Amerika Serikat, atau setara dengan sekitar 2,3 juta orang [15]. AF juga merupakan kelainan jantung yang paling banyak pada kalangan orang tua, dengan usia rata-rata dari mereka yang terkena dampak ini berada pada sekitar 75 tahun. Prevalensi AF meningkat mencapai 8\% pada orang Amerika Serikat yang berusia di atas 80 tahun. Kejadian fibrilasi atrium meningkat dengan bertambahnya usia [16]. Pada abad ke-21 ini semakin meningkat jumlah pasien dengan diagnosis fibrilasi atrium [17]. Pada tahun 2001, jumlah pasien dengan fibrilasi atrium mencapai 2,3 juta di Amerika dan 4,5 juta pasien di Eropa. Dan diperkirakan kejadian fibrilasi atrium akan terus meningkat $0,1 \%$ setiap tahunnya pada populasi umur 40 tahun ke atas, 1,5\% pada wanita, dan $2 \%$ pada lansia dengan umur lebih dari 80 tahun [18]. Angka kejadian fibrilasi atrium di dunia pada tahun 2010 diperkirakan 2,66 miliar dan pada tahun 2050 diperkirakan sejumlah 12 miliar jiwa. Dalam dua dekade ini angka kematian akibat fibrilasi atrium meningkat [19].

\section{METODOLOGI PENELITIAN}

Bahan yang digunakan dalam penelitian ini adalah data fisik electrocardiogram (masih berbentuk data cetak di atas kertas grafik) untuk dua jenis kondisi jantung yang diambil dari Rumah Sakit Umum Daerah Tugurejo Semarang yang selanjutnya dilakukan scanning untuk mendapatkan data digital berupa citra dua dimensi. Jenis data yang diambil adalah data ECG normal berjumlah 20 data dan Atrial Fibrillation (AF) berjumlah 30 data, sehingga jumlah keseluruhan data ada 50 data. Pengolahan isyarat ECG dalam penelitian ini dilakukan melalui beberapa tahapan, diantaranya adalah pra pengolahan, ekstraksi ciri, dan klasifikasi. Tahapan tersebut dapat dilihat pada Gambar 2 di bawah ini. 


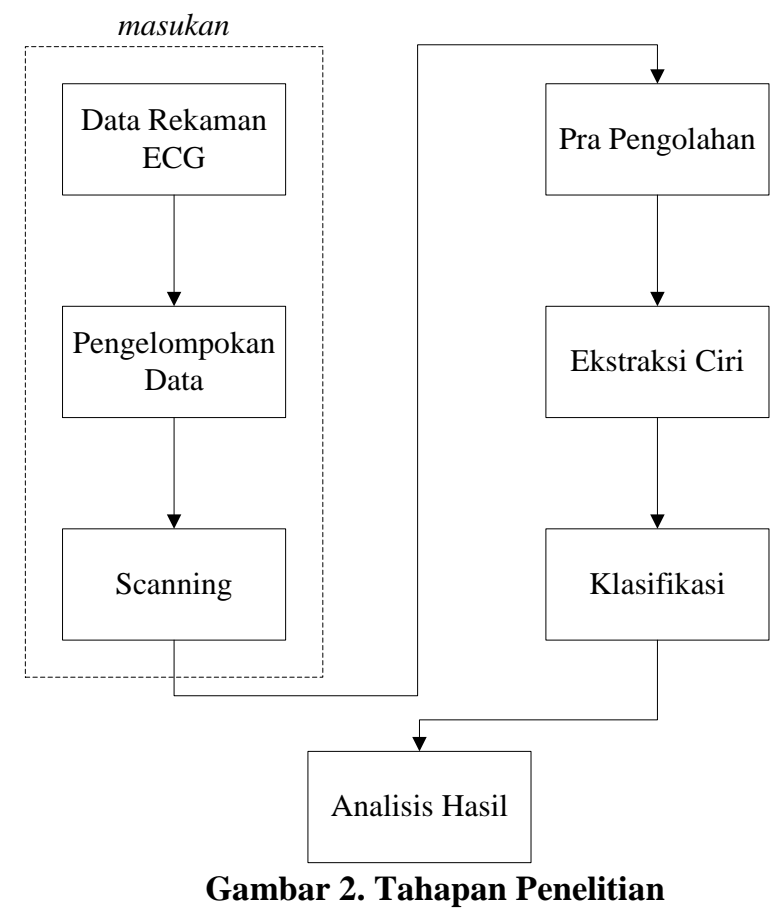

Tahap pra-pengolahan dilakukan untuk mendapatkan data yang lebih baik dari data sebelumnya. Pada tahap ini selain dilakukan segmentasi terhadap citra isyarat ECG juga dilakukan transformasi dari kawasan spasial (spatial domain) ke kawasan waktu (time domain), sehingga didapatkan isyarat ECG dalam domain waktu. Selanjutnya dilakukan proses ekstrasi ciri dari isyarat tersebut. Pada tahapan ekstraksi ciri terlebih dahulu dicari isyarat dari PSD (kerapatan spektrum daya) dengan metode Welch.

Ekstraksi ciri dilakukan bertujuan untuk mendapatkan ciri dari masing-masing jenis isyarat ECG, yaitu isyarat ECG normal atau normal sinus rhythm (NSR) dan atrial fibrillation (AF). Pada tahapan ini, ciri diambil berdasarkan nilai statistik (rata-rata atau mean, simpangan baku atau standard deviation, ragam atau variance, kurtosis, dan skewness) yang dilakukan pada isyarat EKG berdasarkan isyarat periodogramnya. Secara garis besar tahapan ekstraksi ciri dapat dilihat pada Gambar 3 berikut ini.

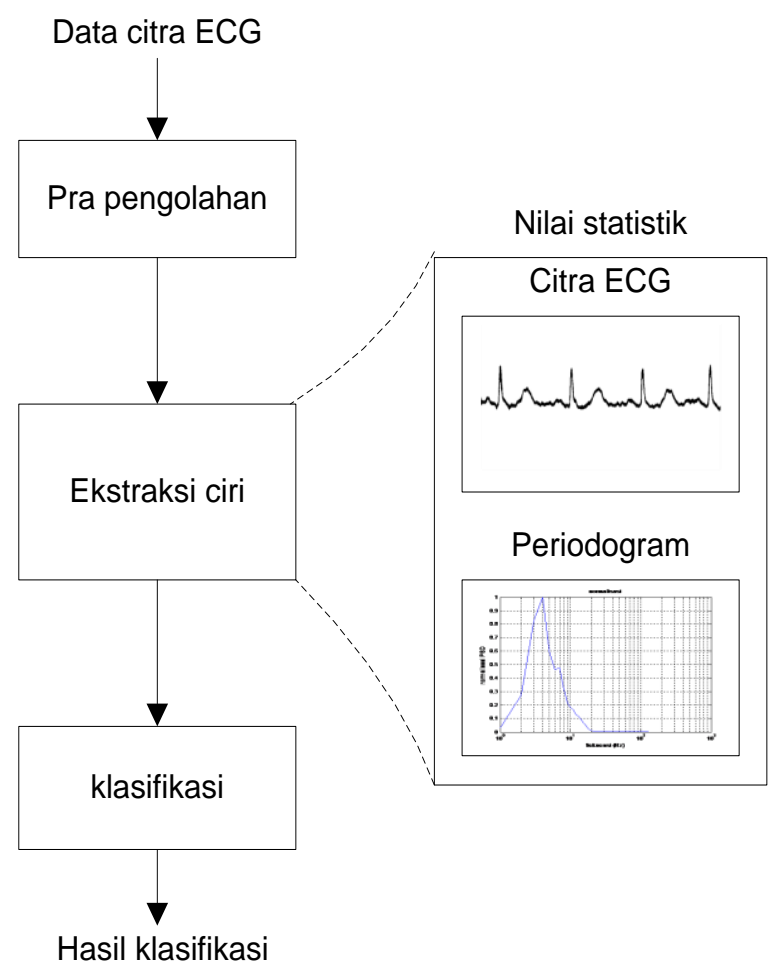

Gambar 3. Tahapan Ekstraksi Ciri 
Ekstraksi ciri statistik diambil dari isyarat PSD ternormalisasi. Ciri statistik yang digunakan adalah :

a. $\operatorname{Mean}(\mu)$

Mean merupakan nilai rata-rata dari beberapa buah data (persamaan 1)

$$
\mu=\frac{1}{N} \sum_{i=0}^{N-1} X_{i}
$$

b. Standar deviasi $(\sigma)$

Standar deviasi atau simpangan baku merupakan akar kuadrat varian (persamaan 2)

$$
\sigma=\sqrt{\frac{1}{N} \sum_{i=0}^{N-1}\left(x_{i}-\mu\right)^{2}}
$$

c. Kurtosis $\left(\alpha^{4}\right)$

Menggambarkan keruncingan (peakedness) atau kerataan (flatness) suatu distribusi data dibandingkan dengan distribusi normal (persamaan 3)

$$
\alpha^{4}=E\left\{y^{4}\right\}-3\left(E\left\{y^{2}\right\}\right)^{2}
$$

d. Varian $\left(\sigma^{2}\right)$

Varian atau ragam suatu peubah acak (distribusi probabilitas) adalah ukuran bagi persebaran atau dispersi data. Yang diukur adalah seberapa jauh data tersebar disekitar rerata (persamaan 4)

$$
\sigma^{2}=\operatorname{var}(x)=\frac{1}{N-1} \sum_{i=0}^{N-1}\left(x_{i}-\mu\right)^{2}
$$

e. Skewness $\left(\alpha^{3}\right)$

Skewnees merupakan pengukuran tingkat ketidaksimetrisan (kecondongan) sebaran data disekitar rata-ratanya (persamaan 5)

$$
\alpha^{3}=\frac{E(x-\mu)^{3}}{\sigma^{3}}
$$

Setelah didapatkan ciri statistik tersebut selanjutnya diklasifikasi dengan metode Support Vector Machine (SVM). Secara sederhana algoritma SVM merupakan sistem pembelajaran yang pengklasifikasianya menggunakan ruang hipotesis berupa fungsi-fungsi linear dalam sebuah ruang fitur (feature space) berdimensi tinggi, dilatih dengan algoritme pembelajaran yang didasarkan pada teori optimasi dengan mengimplementasikan learning bias yang berasal dari teori pembelajaran statistik. Dalam konsep SVM berusaha menemukan fungsi pemisah (hyperplane) terbaik diantara fungsi yang tidak terbatas jumlahnya. Hyperplane pemisah terbaik antara kedua kelas dapat ditemukan dengan mengukur margin hyperplane tersebut dan mencari titik maksimalnya.

Pengujian terhadap metode klasifikasi yang diterapkan dalam penelitian ini dengan cara menghitung nilai akurasi , sensitivitas , dan spesifisitas. Masing-masing dapat dicari dengan persamaan 6-8 berikut ini.

Akurasi $=\frac{T P+T N}{T P+F P+T N+F N}$

Sensitivitas $=\frac{T P}{T P+F N}$

Spesifisitas $=\frac{T N}{F P+T N}$

Dimana $T P=$ True Positive, $F P=$ False Positive, $T N=$ True Negative, $F N=$ False Negative

Selanjutnya sebagai bahan evaluasi untuk mendapatkan hasil estimasi akurasi pada penelitian ini menggunakan metode cross validation dengan fold=5. Sehingga jumlah dari keseluruhan data akan dibagi kedalam 5 bagian yang sama. Jika terdapat 50 instances (sampel) maka akan terdapat 5 blok dengan masing-masing blok terdiri dari 10 instance. Jika kelima blok tersebut adalah A,B,C,D,dan E, maka pengujian dilakukan dengan cara sebagai berikut :

Step 1 : training memakai A,B,C,D dan testing mamakai E $\rightarrow$ akurasi $a$

Step 2 : training memakai A,B,C,E dan testing mamakai D $\rightarrow$ akurasi $b$ 
Step 3 : training memakai A,B,D,E dan testing mamakai $\mathrm{C} \rightarrow$ akurasi $c$

Step 4 : training memakai A,C,D,E dan testing mamakai B $\rightarrow$ akurasi $d$

Step 5 : training memakai B,C,D,E dan testing mamakai $\mathrm{A} \rightarrow$ akurasi $e$

Sehingga rata-rata akurasi didapatkan dengan menggunakan persamaan 9 di bawah ini.

$\frac{\mathbf{a}+\mathbf{b}+\mathbf{c}+\mathbf{d}+\mathbf{e}}{\mathbf{5}}$

\section{HASIL DAN PEMBAHASAN}

\subsection{Pra-Pengolahan}

Pra-pengolahan dilakukan untuk mendapatkan data yang lebih baik dari data sebelumnya (data asli). Dengan cara memanipulasi parameter-parameter yang terdapat pada data tersebut. Sehingga didapatkan bentuk yang lebih cocok terhadap nilai-nilai yang diinginkan. Operasi pra pengolahan yang dilakukan dimulai dengan pengolahan citra rekaman ECG hasil scanning sebelumnya, sehingga diperoleh citra yang memiliki ukuran dan dimensi serta sebaran warna (nilai piksel) sesuai dengan yang diinginkan sehingga dapat digunakan untuk proses selanjutnya. Tahap pertama yang dilakukan adalah cropping citra atau memotong suatu bagian dari citra sehingga diperoleh citra berukuran lebih kecil. Langkah selanjutnya adalah segmentasi.

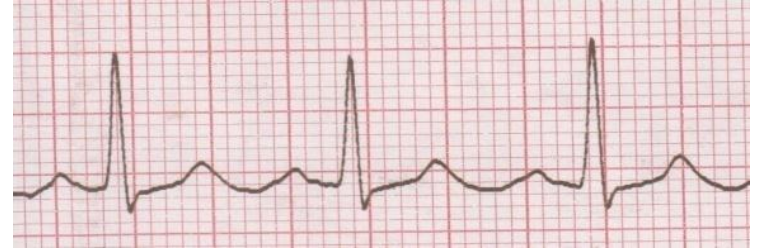

(a)

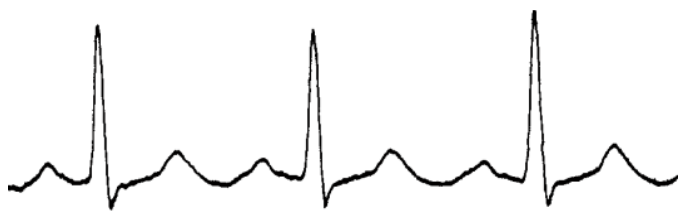

(b)

Gambar 3. (a) Citra Hasil Scanning EKG (b) Hasil Segmentasi Citra EKG

Segmentasi dilakukan untuk mendapatkan citra yang hanya terdiri dari objek yang diinginkan dan membuang objek lain yang dapat mengganggu proses selanjutnya seperti pada Gambar 3. pada tahap ini sebelumnya citra diubah kedalam bentuk citra keabuan atau grayscale, kemudian dilakukan pemfilteran dengan mengguanakna median filter. Citra hasil filter diubah ke dalam citra biner yang hanya terdiri dari warna hitam dan putih saja. Setelah didapatkan citra biner kemudian dilakukan operasi morfologi closing. Operasi morfologi ini berfungsi untuk menghilangkan bagian detail yang terlihat gelap dan menyisakan bagian terang yang tidak mengganggu. Langkah selanjutnya adalah melakukan transformasi kawasan spasial ke kawasan waktu.

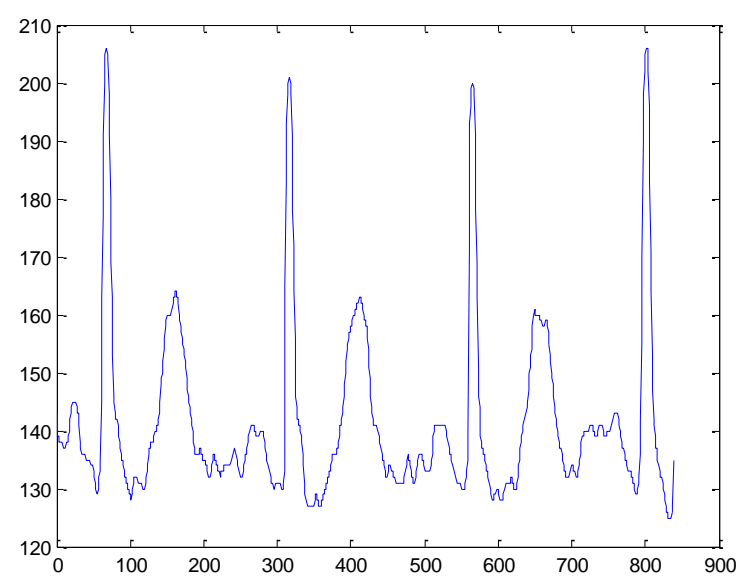

Gambar 4. Hasil Konversi Ke Satu Dimensi

Proses ini mengubah citra dua dimensi menjadi satu dimensi (Gambar 4). Hasil yang didapat tinggi citra dari isyarat menjadi penggambaran amplitudo isyarat dan pergeseran pembacaan menjadi penunjuk 
waktu, jika citra mempunyai resolusi 600 dpi maka setiap 25,4 mm (1 inch) terdapat 600 piksel. Dengan demikian lebar citra (x) dalam ukuran mm adalah

$\frac{x}{600} \times 25,4 \mathrm{~mm}$

dan untuk tinggi isyarat adalah

$$
\frac{y}{600} \times 25,4 \mathrm{~mm}
$$

Karena besaran yang ada pada isyarat adalah amplitudo dan waktu maka sumbu y (tinggi isyarat) diubah kedalam satuan $\mathrm{mV}$ dimana dalam EKG $1 \mathrm{~mm}$ menunjukkan $0,1 \mathrm{mV}$ sehingga amplitudo isyarat adalah y x $0,1 \mathrm{mV}$. Sedangkan pada pengukuran sumbu x (lebar isyarat) diubah ke dalam satuan waktu (detik). Laju perekaman yang dipakai adalah $25 \mathrm{~mm} /$ detik, maka $1 \mathrm{~mm}$ setara dengan 0,04 detik, sehingga waktu isyarat $(\mathrm{t})$ diperoleh dengan mengalikan $x$ x 0,04 detik.

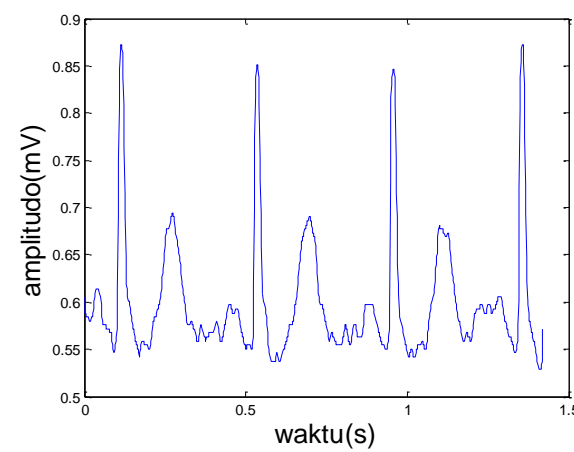

(a)

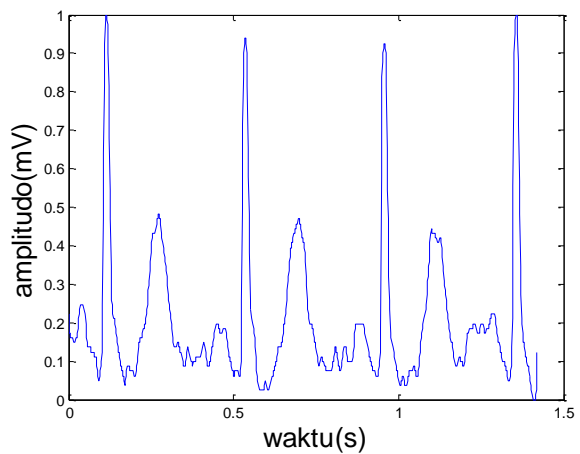

(b)

Gambar 5. (a) Isyarat Dalam Kawasan Waktu, (b) Isyarat Setelah Dinormalisasi

Setelah berubah dalam kawasan waktu, maka kemudian dilakukan normalisasi sehingga didapatkan isyarat yang tampak seperti pada gambar 5 di atas. Isyarat hasil transformasi dinormalisasi dengan tujuan menyederhanakan bentuk isyarat agar pengolahan lebih efektif.

Langkah terakhir pada tahap proses pra pengolahan adalah baseline wander removal. Penghapusan derau baseline wander dapat dilakukan dengan menggunakan transformasi wavelet diskrit. Prinsip dasar dari transformasi wavelet diskrit adalah bagaimana cara mendapatkan representasi waktu dan skala dari sebuah isyarat menggunakan teknik pemfilteran digital dan operasi sub-sampling. Isyarat EKG pertamatama dilewatkan pada rangkaian filter high-pass dan low-pass, kemudian setengah dari masing-masing keluaran diambil dengan sampel melalui operasi sub-sampling. Proses ini disebut sebagai proses dekomposisi satu tingkat. Keluaran filter low-pass digunakan sebagai masukan proses dekomposisi tingkat berikutnya. Proses ini diulang sampai tingkat proses dekomposisi yang diinginkan. Pada penelitian ini isyarat EKG didekomposisi hingga tingkat 11, sehingga diperoleh komponen frekuensi rendah yang menjadi penyebab derau baseline wander. Hal ini dapat dilihat pada Gambar 6 dibawah ini.
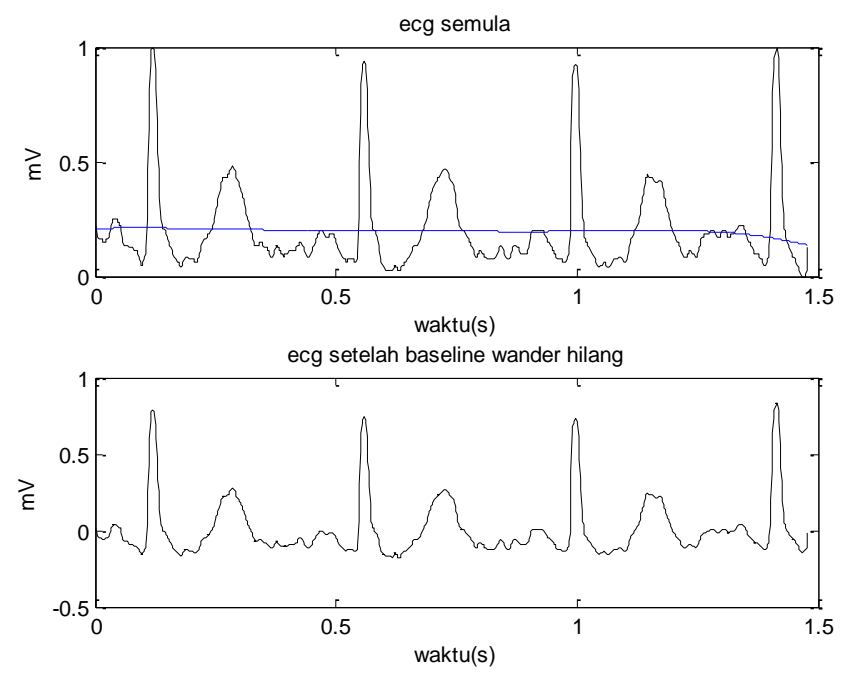

Gambar 6. Isyarat Tanpa Derau Baseline Wander 


\subsection{Ekstraksi Ciri}

Proses ekstraksi ciri dilakukan bertujuan untuk mendapatkan ciri dari masing-masing jenis isyarat ECG, yaitu isyarat ECG normal atau normal sinus rhythm (NSR) dan atrial fibrillation (AF). Ciri yang diambil merupakan nilai statistik isyarat PSD (power spectral density) ternormalisasi dari isyarat EKG (gambar 7). Nilai statistik yang digunakan adalah mean, standard deviation, kurtosis, variance, dan skewness.
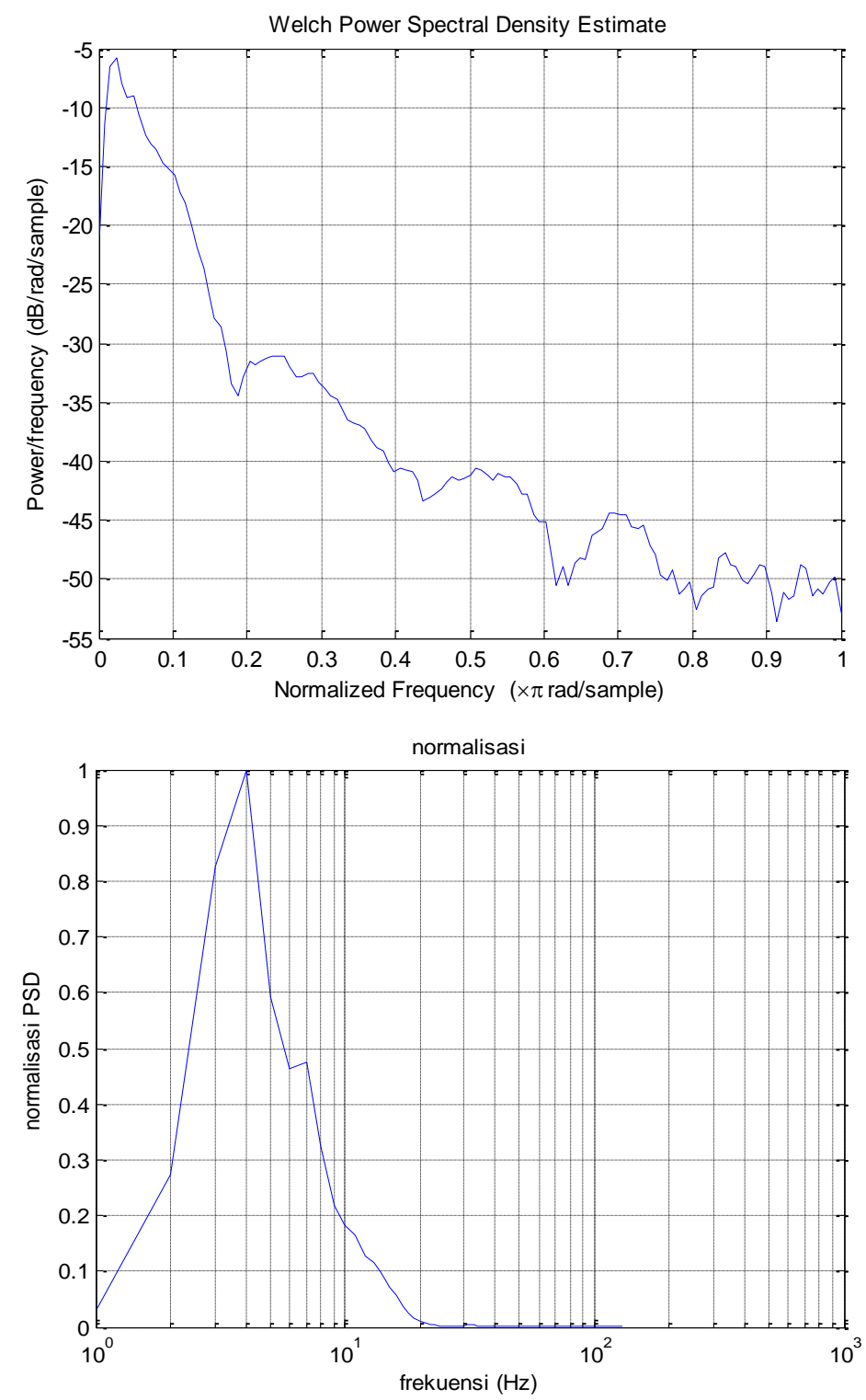

Gambar 7. Isyarat Power Spectral Density (PSD)

Dari grafik isyarat diatas dapat dicari ciri statistiknya, sehingga setiap data masing-masing diperoleh seperti pada tabel 1 berikut ini.

Tabel 1. Ciri statistik dari isyarat periodogram

\begin{tabular}{ccccc}
\hline Mean & Std deviasi & Varian & Kurtosis & Skewnes \\
\hline 0,0402 & 0,1427 & 0,0204 & 26,6617 & 4,6916 \\
\hline
\end{tabular}

Setelah didapatkan ciri statistiknya maka langkah selanjutnya adalah proses klasifikasi dengan algoritma Support Vector Machine (SVM). 


\subsection{Klasifikasi}

Klasifikasi merupakan proses penemuan model atau fungsi yang menggambarkan dan membedakan kelas data atau konsep yang bertujuan agar bisa digunakan untuk memprediksi kelas dari objek yang label kelasnya tidak diketahui. Metode klasifikasi yang digunakan pada penelitian ini adalah Support Vector Machine (SVM) dan Nä̈ve bayes Classifier (NBC) sebagai algoritma pembanding.

Support Vector Machine (SVM) merupakan sistem pembelajaran yang pengklasifikasianya menggunakan ruang hipotesis berupa fungsi-fungsi linear dalam sebuah ruang fitur (feature space) berdimensi tinggi, dilatih dengan algoritme pembelajaran yang didasarkan pada teori optimasi dengan mengimplementasikan learning bias yang berasal dari teori pembelajaran statistik. Dalam konsep SVM berusaha menemukan fungsi pemisah (hyperplane) terbaik diantara fungsi yang tidak terbatas jumlahnya. Hyperplane pemisah terbaik antara kedua kelas dapat ditemukan dengan mengukur margin hyperplane tersebut dan mencari titik maksimalnya. SVM telah berhasil digunakan dalam pengenalan pola. Pembelajaran dilakukan dengan menggunakan pasangan data input dan data output berupa sasaran yang diinginkan. Pembelajaran dengan cara ini disebut dengan pembelajaran terarah (supervised learning). Dengan pembelajaran terarah ini akan diperoleh fungsi yang menggambarkan bentuk ketergantungan input dan outputnya. Selanjutnya, diharapkan fungsi yang diperoleh mempunyai kemampuan generalisasi yang baik, dalam arti bahwa fungsi tersebut dapat digunakan untuk data input diluar data pembelajaran. Akurasi prediksi umumnya tinggi, kuat bekerja ketika contoh pelatihan mengandung kesalahan, dan evaluasi cepat dari fungsi target belajar merupakan kelebihan dari SVM. Pada penelitian ini jenis kernel yang digunakan adalah radial basis function atau RBF kernel. Hasilnya disajikan dalam bentuk confusion matrix yang dapat dilihat pada Tabel 2 di bawah ini.

Tabel 2. Confusion matrix hasil identifikasi AF dengan SVM

\begin{tabular}{cc}
\hline $\mathrm{TP}=29$ & $\mathrm{FN}=7$ \\
\hline $\mathrm{FP}=1$ & $\mathrm{TN}=13$ \\
\hline
\end{tabular}

Berdasarkan Tabel 2 di atas maka didapatkan hasil dari kinerja klasifikasi dengan metode SVM berdasarkan ciri statistik yang diambil dari isyarat periodogram adalah akurasi sebesar $84,0 \%$ dengan sensitivitas sebesar $80,5 \%$ dan spesifisitas $92,8 \%$.

Sedangkan Naive bayes Classifier (NBC) merupakan salah satu algoritme klasifikasi statistik yang menerapkan teori bayes yang dapat digunakan untuk memprediksi keanggotaan suatu kelas. Teori bayesian pada dasarnya adalah kemungkinan kejadian dimasa depan yang bisa dihitung dengan menentukan frekuensi pengalaman sebelumnya. Penggunaan algoritme bayes dalam hal klasifikasi harus mempunyai masalah yang bisa dilihat statistiknya. HMAP (Hypothesis Maximum Appropri Probability) menyatakan hipotesis yang diambil berdasarkan nilai probabilitas berdasarkan kondisi prior atau sebelumnya yang diketahui. HMAP inilah yang digunakan didalam machine learning sebagai metode untuk mendapatkan hipotesis untuk suatu keputusan. Penerapan metode klasifikasi naive bayes classifier (NBC) yang telah diterapkan dalam penelitian ini hasilnya dapat dilihat pada tabael 3 dibawah ini.

Tabel 3. Confusion matrix hasil identifikasi AF dengan NBC

\begin{tabular}{cc}
\hline $\mathrm{TP}=25$ & $\mathrm{FN}=4$ \\
\hline $\mathrm{FP}=5$ & $\mathrm{TN}=16$ \\
\hline
\end{tabular}

Berdasarkan Tabel 3 di atas maka didapatkan hasil dari kinerja klasifikasi dengan metode NBC berdasarkan ciri statistik yang diambil dari isyarat periodogram adalah $82,0 \%, 86,2 \%$, dan $76,1 \%$ dalam hal akurasi, sensitivitas dan spesifisitas.

Sehingga setelah didapatkan hasil dari klasifikasi dari masing-masing algoritma, maka untuk melihat lebih jelas dapat dilihat dengan kurva ROC(Receiver Operating Characteristic) yang dapat menggambarkan dari kinerja masing-masing metode yaitu SVM dan NBC yang tampak pada gambar 8 berikut ini. 


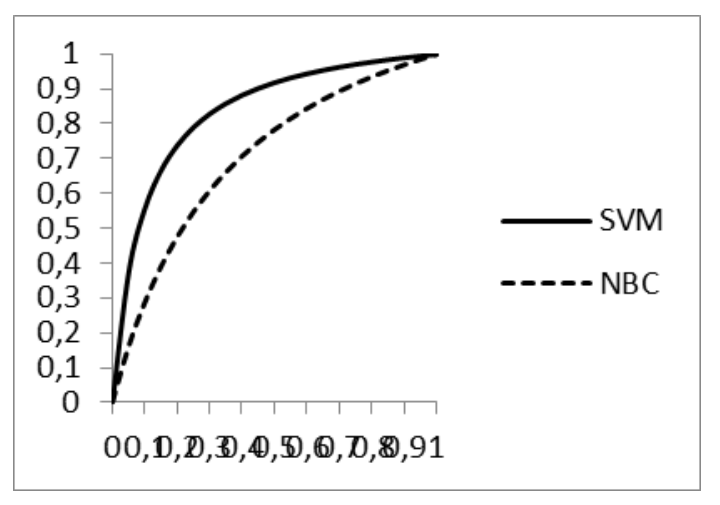

Gambar 8. Kurva ROC algoritma SVM dan NBC

Berdasarkan kurva ROC yang terdapat pada Gambar 8 di atas telah didapatkan nilai AUC (Area Under ROC Curve) pada masing-masing algoritme yaitu $\mathrm{SVM}=0,867$ atau $86,7 \%$, dan $\mathrm{NBC}=0,812$ atau $81,2 \%$. Sehingga dari nilai AUC tersebut dapat dikatakan bahwa algoritme SVM menunjukkan kinerja yang lebih baik dari lagoritma pembanding yaitu NBC yang telah digunakan karena memiliki nilai AUC yang paling besar atau hampir mendekati nilai $100 \%$. Karena pada dasarnya nilai AUC memiliki rentang antara 50\% (0,5) sampai dengan 100\% (1). Nilai AUC 50\% merupakan nilai AUC terburuk, sedangkan nilai AUC 100\% merupakan nilai yang terbaik.

\section{KESIMPULAN}

Dari berbagai tahapan yang telah dilakukan dalam penelitian ini menunjukkan bahwa ekstraksi ciri statistik yang diambil dari isyarat periodogram dapat dijadika sebuah ciri atau feature untuk identifikasi aritmia jenis atrial fibrillation (AF) berdasarkan isyarat elektrokardiogram (EKG). Sedangkan untuk klasifikasi, algoritma Support Vector Machine (SVM) untuk mengidentifikasi aritmia jenis atrial fibrillation $(A F)$ mendaptakan hasil lebih baik dengan penilaian index kinerja klasifikasi dihasilkan akurasi sebesar $84,0 \%$, sensitivitas $80,5 \%$, dan spesifisitas $92,8 \%$ dengan nilai AUC $=0,867$. Sedangkan untuk NBC didapatkan $82,0 \%, 86,2 \%, 76,1 \%$ dalam hal akurasi, sensitivitas dan spesifisitas dengan nilai AUC sebesar 0,812 .

\section{DAFTAR PUSTAKA}

[1] WHO and World Health Organisation, "The 10 leading causes of death in the world, 2000 and 2012," 2014.

[2] L. Sherwood, "Human Physiology: From Cells to Systems," Hum. Physiol., vol. 7th editio, p. 766, 2010.

[3] J. E. Hall and A. C. Guyton, Guyton and Hall Textbook of Medical Physiology, vol. 53. 2011.

[4] D. Waller, "A Demonstration On Man Of Electromotive Changes Accompanying The Heart's Beat," J Physiol, p. 8(5): 229-234.

[5] R. Rangayyan, "Biomedical signal analysis," Library.Wisc.Edu. 2002.

[6] Chaudhuri, Subhasis, Pawar, T. D., Duttagupta, and Siddhartha, Ambulation Analysis in Wearable ECG. 2009.

[7] Braunwald E., Heart Disease: A Textbook of Cardiovascular Medicine, Fifth. Philadelphia, 1997.

[8] M. Velic, I. Padavic, and S. Car, "Computer aided ECG analysis - State of the art and upcoming challenges," IEEE EuroCon 2013, no. July, pp. 1778-1784, 2013.

[9] E. A. Sobie et al, "Regression methods for parameter sensitivity analysis: applications to cardiac arrhythmia mechanisms," Conf Proc IEEE Eng Med Biol Soc, pp. 4657-4660, 2011.

[10] A. B. A. Bollmann and F. L. F. Lombardi, "Electrocardiology of atrial fibrillation," IEEE Eng. Med. Biol. Mag., vol. 25, no. December, pp. 15-23, 2006.

[11] C. a Sanoski, "Clinical, economic, and quality of life impact of atrial fibrillation.," J. Manag. Care Pharm., vol. 15, no. 6 Suppl B, pp. S4-S9, 2009.

[12] E. Berry and H. Padgett, "Management of patients with atrial fibrillation: diagnosis and treatment.," Nurs. Stand., vol. 26, no. 22, pp. 47-56, 2012.

[13] A. J. Camm et al., "Guidelines for the management of atrial fibrillation," European Heart Journal, vol. 31, no. 19. pp. 2369-2429, 2010.

[14] S. S. Nijjer and D. C. Lefroy, “Atrial fibrillation.," Br. J. Hosp. Med. (Lond)., vol. 73, no. 5, pp. C69-73, 2012. 
[15] M. Lainscak et al, "Atrial fibrillation in chronic non-cardiac disease: Where do we stand?," International Journal of Cardiology, vol. 128, no. 3. pp. 311-315, 2008.

[16] G. Chatap, K. Giraud, and J.-P. Vincent, "Atrial fibrillation in the elderly: facts and management.," Drugs Aging, vol. 19, no. 11, pp. 819-846, 2002.

[17] Sacchetti et al, "Impact of emergency department management of atrial fibrillation on hospital charges," Western Journal of Emergency Medicine, vol. 14, no. 1. pp. 55-57, 2013.

[18] European Heart Rhythm Association et al., "Guidelines for the management of atrial fibrillation: the Task Force for the Management of Atrial Fibrillation of the European Society of Cardiology (ESC).," Europace, vol. 12, no. 10, pp. 1360-420, 2010.

[19] S. J. Connolly, “Atrial fibrillation in 2010: advances in treatment and management.," Nat. Rev. Cardiol., vol. 8, no. 2, pp. 67-68, 2011. 